\title{
Inoculation methods and aggressiveness of five Fusarium species against peach palm
}

\author{
Tiago Miguel Jarek ${ }^{1^{*}} \odot$ Álvaro Figueredo dos Santos $^{2}$ \\ Dauri José Tessmann ${ }^{3}$ Elisa Serra Negra Vieira ${ }^{2}$
}

${ }_{1}^{1}$ Universidade Federal do Paraná (UFPR), 80035-050, Curitiba, PR, Brasil. E-mail: tiagomiguel87@yahoo.com.br. "Corresponding author. ${ }^{2}$ Empresa Brasileira de Pesquisa Agropecuária (Embrapa Florestas), Colombo, PR, Brasil.

${ }^{3}$ Universidade Estadual de Maringá (UEM), Maringá, PR, Brasil.

\begin{abstract}
Fusarium wilt is a major disease which affects peach palm (Bactris gasipaes Kunth.var gasipaes Henderson). This study aimed to evaluate inoculation methods and aggressiveness of isolates of five Fusarium species on peach palm. Fusarium proliferatum can infect the leaves, stem, and roots of peach palm. F. proliferatum, F. oxysporum species complex (FOSC), F. verticillioides, F. solani species complex (FSSC), and Gibberella fujikuroi species complex (GFSC) are pathogenic to peach palm. The use of Fusarium-colonized ground corn for root inoculation was effective and reduced the level of damage to plants.
\end{abstract}

Key words: Bactris gasipaes, heart of palm, Fusarium wilt.

Métodos de inoculação e agressividade de cinco espécies de Fusarium à pupunheira

RESUMO: A fusariose é uma das principais doenças da pupunheira (Bactris gasipaes Kunth.var gasipaes Henderson). O objetivo deste trabalho foi avaliar métodos de inoculação e a agressividade de isolados de cinco espécies de Fusarium à pupunheira. Demonstrou-se que Fusarium proliferatum pode infectar folhas, caule e raizes de pupunheira. Verificou-se que as espécies F. proliferatum, F. oxysporum species complex (FOSC), F. verticillioides, F. solani species complex (FSSC) e Gibberella. fujikuroi species complex (GFSC) são patogênicas à pupunheira e, que o uso da quirera colonizada por Fusarium para inoculação de raízes foi efetivo e reduziu o nível de injúrias às plantas. Palavras-chave: Bactris gasipaes, Kunth, palmito, fusariose.

\section{INTRODUCTION}

Peach palm (Bactris gasipaes var. gasipaes Henderson) plantations for heart of palm production have expanded in recent years in several Brazilian states including Bahia, Goiás, São Paulo, Mato Grosso, and Santa Catarina. Its importance is mainly attributed to the substitution of the "Juçara" heart-of-palm (Euterpe edulis Martius), exploited in an extractive manner in the Atlantic Forest, by a cultivated palm allowing successive cuts for several years. Peach palm exhibits differentiated characteristics, such as tillering, precocity, and no oxidation of the heart of palm after cutting, enabling its in natura commercialization (SANTOS et al., 2008).

Fusariosis, caused by Fusarium spp., is a major disease which affects the peach palm.
Fusariosis causes leaf yellowing, which progresses until the plant death, and occasionally, of clump, with reduction of stands in nurseries and adult plantations (PIZZINATTO et al., 2001). Fusarium can be disseminated by seeds, and it is present in the main production areas in Brazil (SANTOS et al., 2008; COSTA JÚNIOR et al., 2016). According to COSTA JÚNIOR et al. (2016), fusariosis may be limiting factor for the expansion of peach palm plantations.

Several Fusarium species (F. proliferatum, $F$. verticillioides, $F$. anthophilum, F. oxysporum, $F$. solani, and F. subglutinans) are linked to peach palm fusariosis (PIZZINATTO et al., 2001; ALMEIDA et al., 2005). However, information on the aggressiveness of these species against the peach palm and appropriate methods of pathogen inoculation is lacking. 
One difficulty in studying fusariosis is related to the inoculation methods (COSTA et al., 2012; KLINGELFUSS et al., 2007). Studies have experienced difficulty in reproducing the same results (PIZZINATO et al., 2001; COSTA JÚNIOR, 2013). The symptoms observed in the field are not reproduced in inoculation tests, taking up to eight weeks for typical symptoms appearance (ALVES et al., 2006, PIZZINATTO et al., 2001). Furthermore, extensive injury to inoculated plants has been reported, resulting in plant death due to injuries caused during inoculation (COSTA JÚNIOR, 2013). Additionally, some studies produced non-reproducible results in successive experiments using the same strain (PIZZINATO et al., 2001; COSTA JÚNIOR, 2013). Thus, the objective of this research was to evaluate inoculation methods and aggressiveness of isolates of five Fusarium species against peach palm.

\section{MATERIALS AND METHODS}

\section{Origin of isolates of Fusarium spp.}

Thirty-one isolates of Fusarium spp. were collected from five Brazilian states (Table 1) from the Fungi collection of the Forest Pathology Laboratory (Embrapa Florestas, Colombo-PR). They included $F$. proliferatum, $F$. verticillioides, $F$. oxysporum species complex (FOSC), Fusarium solani species complex (FSSC), and Gibberella fujikuroi species complex (GFSC). The Fusarium spp. isolates were obtained from peach palm plants with fusariosis symptoms from plantations located in the states of São Paulo, Rondônia, Paraná, and Santa Catarina.

\section{Preparation of inoculums}

The Fusarium spp. isolates were grown on potato dextrose agar (PDA) medium for 15 days in the dark at $24^{\circ} \mathrm{C}$. Conidial suspensions were each added to $10 \mathrm{~mL}$ of sterile distilled water in a Petri dish and calibrated using a Neubauer chamber to reach 1 $\times 10^{6}$ conidia $\cdot \mathrm{mL}^{-1}$. To prepare ground corn (broken corn passed through a 1.6-mm sieve) for culturing Fusarium spp. isolates, the material was autoclaved for 30 minutes at $121^{\circ} \mathrm{C}$ and one atmosphere. Subsequently, five discs ( $4 \mathrm{~mm}$ in diameter) of PDA medium with Fusarium mycelia were added to flasks containing ground corn (200g of ground corn and $40 \mathrm{~mL}$ of water) as described by COSTA et al. (2012). Flasks were incubated for 15 days.

Experiment 1. Inoculation of $F$. proliferatum onto leaves, stems, and roots

The abaxial sides of leaves of fourmonth-old seedlings with an average height of $10 \mathrm{~cm}$ were inoculated with a conidial suspension of $F$. proliferatum [SP-3 isolate, analyzed in a previous study (COSTA JÚNIOR, 2013)] using a fine needle syringe with a diameter of $0.4 \mathrm{~mm}$. Ten replicates were used, with each replicate being one plant. Two treatments were used: pathogen and control. Conidial suspension was infiltered through the mesophyll leaf until it was possible to visualize a wet region. In the control treatment, the same procedure was performed using only infiltered saline solution $(0.85 \% \mathrm{NaCl})$ on the leaves.

Stems of 10 peach palm seedlings were inoculated using the wounding method in the basal region, and a micro-drop of $5 \mu \mathrm{L}$ of the suspension $\left(1 \times 10^{6}\right.$ conidia $\left.\cdot \mathrm{mL}^{-1}\right)$ was deposited on the wounded region. This wound was created using a needle $1.6 \mathrm{~mm}$ in diameter. F. Proliferatum isolate SP-3 was used. For the third inoculation, roots were washed and $20 \mu \mathrm{L}$ of the conidial suspension $(1 \times$ $10^{6}$ conidia $\left.\cdot \mathrm{mL}^{-1}\right)$ was injected into three young roots using a syringe equipped with a fine needle. The control group received only one injection with water. Evaluations were conducted weekly using a diagrammatic scale (COSTA JÚNIOR, 2013) to determine the severity of the disease.

Experiment 2. Evaluation of aggressiveness of 31 isolates of five Fusarium species

Injured stems were infected with the conidial suspension, and the conduction of 10 plants per isolate was analyzed in tubes (adapted from DIHAZI et al. (2012)). Assessments were performed weekly to determine the incidence and severity of the disease using a diagrammatic scale (COSTA JÚNIOR, 2013). When plants reached grade four, the pathogen was reisolated. The injured tissue fragments were disinfected with $70 \%$ ethanol for 30 s and $1 \%$ sodium hypochlorite for $1 \mathrm{~min}$, and added to PDA medium. At the end of the experiment, a longitudinal cut was made in the stem and internal lesions were evaluated. Plants were distributed in a completely randomized design with 10 replicates. Each plant was an experimental unit, and the Scott-Knott test at 5\% significance was conducted to determine the means of the five largest internal lesions.

Experiment 3. Comparison of methods of Fusarium inoculation onto roots

In this experiment, four methods of Fusarium sp. inoculation were evaluated. The first method was root inoculation with conidial suspension. Roots were inoculated via injection as described above. However, plants were maintained in sterile commercial substrate. Plants of the control group 
Table 1 - Aggressiveness against peach palm and origin of isolates of Fusarium proliferatum, F. oxysporum species complex (FOSC), F. verticillioides; $F$. solani species complex (FSSC), and Gibberella fujikuroi species complex (GFSC) via inoculation of stem after wounding.

\begin{tabular}{|c|c|c|c|c|c|c|c|}
\hline \multirow[t]{2}{*}{ Species } & \multirow[t]{2}{*}{ Strain } & \multirow[t]{2}{*}{ Origin } & \multicolumn{2}{|c|}{ External symptoms } & \multicolumn{3}{|c|}{ Internal symptoms } \\
\hline & & & $\operatorname{INC}(\%)$ & $\mathrm{SEV}^{1}$ & $\operatorname{INC}(\%)$ & & \\
\hline & Control & & $\mathrm{A}^{*}$ & $\mathrm{~B}^{* *}$ & $\mathrm{~A}^{*}$ & 4.2 & $b^{B^{*}}$ \\
\hline & $\mathrm{SP}-5$ & RO & 30 & 1.2 & 50 & 17.6 & $\mathrm{a}$ \\
\hline & Fus -13 & PR & 0 & 0 & 30 & 6.6 & $\mathrm{~b}$ \\
\hline & $\mathrm{SP}-3$ & RO & 0 & 0 & 100 & 15.5 & $\mathrm{a}$ \\
\hline & Fus -12 & PR & 0 & 0 & 70 & 12.3 & $\mathrm{a}$ \\
\hline & Fus -2 & PR & 0 & 0 & 60 & 11.6 & $\mathrm{a}$ \\
\hline \multirow[t]{10}{*}{$F$. proliferatum } & $\mathrm{GA}-3$ & $\mathrm{SC}$ & 20 & 0.8 & 60 & 11.4 & $\mathrm{~b}$ \\
\hline & $\mathrm{SAF}-2$ & PR & 10 & 0.4 & 30 & 4.1 & $\mathrm{~b}$ \\
\hline & $\mathrm{CA}-1 \mathrm{~A}$ & SP & 50 & 2 & 60 & 9.6 & $\mathrm{~b}$ \\
\hline & SP - 3HR & RO & 10 & 0.1 & 50 & 6.2 & $\mathrm{~b}$ \\
\hline & $\mathrm{SAF}-4$ & PR & 30 & 1.2 & 80 & 11.4 & $\mathrm{a}$ \\
\hline & $\mathrm{SAF}-7$ & PR & 0 & 0 & 80 & 13.4 & $\mathrm{a}$ \\
\hline & $\mathrm{SAF}-8$ & PR & 0 & 0 & 80 & 7.6 & $\mathrm{~b}$ \\
\hline & $1 \mathrm{~A}$ & RO & 20 & 0.6 & 50 & 19.6 & $\mathrm{a}$ \\
\hline & $1 \mathrm{~A} 02 \mathrm{E}$ & RO & 30 & 0.6 & 100 & 30.3 & $\mathrm{a}$ \\
\hline & A7 & RO & 10 & 0.4 & 40 & 4.3 & $\mathrm{~b}$ \\
\hline \multirow[t]{5}{*}{ FOSC } & $\mathrm{BG}-11$ & PR & 10 & 0.1 & 80 & 11.1 & $\mathrm{a}$ \\
\hline & $\mathrm{GA}-1$ & $\mathrm{SC}$ & 20 & 0.3 & 60 & 19.3 & $\mathrm{a}$ \\
\hline & $\mathrm{BG}-14$ & MG & 80 & 2.4 & 60 & 4.3 & $\mathrm{~b}$ \\
\hline & $\mathrm{CA}-1 \mathrm{~B}$ & $\mathrm{SP}$ & 0 & 0 & 40 & 6.3 & $\mathrm{~b}$ \\
\hline & $\mathrm{CA}-2$ & SP & 10 & 0.4 & 90 & 14.2 & $\mathrm{a}$ \\
\hline F. verticillioides & $3 \mathrm{~A}$ & RO & 10 & 0.2 & 50 & 13.2 & $\mathrm{a}$ \\
\hline \multirow{5}{*}{ FSSC } & $\mathrm{BG}-13$ & PR & 0 & 0 & 50 & 13.0 & $\mathrm{a}$ \\
\hline & $\mathrm{SP}-2$ & RO & 20 & 0.6 & 50 & 4.6 & $\mathrm{~b}$ \\
\hline & $\mathrm{BG}-21$ & PR & 20 & 0.8 & 80 & 7.3 & $\mathrm{~b}$ \\
\hline & $\mathrm{BG}-2$ & PR & 0 & 0 & 50 & 6.5 & $\mathrm{~b}$ \\
\hline & $\mathrm{SAF}-5$ & PR & 10 & 0.2 & 70 & 15.3 & $\mathrm{a}$ \\
\hline \multirow[t]{5}{*}{ GFSC } & $\mathrm{BG}-12$ & PR & 10 & 0.4 & 50 & 4.2 & $\mathrm{~b}$ \\
\hline & $\mathrm{CA}-3$ & SP & 0 & 0 & 60 & 13.5 & $\mathrm{a}$ \\
\hline & $\mathrm{BG}-15$ & PR & 20 & 0.6 & 60 & 10.2 & $\mathrm{a}$ \\
\hline & $\mathrm{SAF}-6$ & PR & 0 & 0 & 50 & 9.0 & $\mathrm{~b}$ \\
\hline & $\mathrm{SAF}-3$ & PR & 0 & 0 & 100 & 21.1 & $\mathrm{a}$ \\
\hline \multicolumn{3}{|c|}{ Coefficient of Variation $\%$} & & & & 43,4 & \\
\hline
\end{tabular}

INC, Incidence (percentage of plants with symptoms); SEV ${ }^{1}$, Severity -Scale with grades from 0 to 4; SEV ${ }^{2}$, Severity -Stem lesion size $(\mathrm{mm}) ;{ }^{*}$ Numbers followed by the same letter within the column do not differ statistically, Scott-Knott test, $\mathrm{p}<0.05$; $\mathrm{A}^{*} \mathrm{Plants}$ of the control group suffered injuries during inoculation, resulting in the death of certain plants. B* Owing to injuries, the control plants exhibited leaf

were injected only with sterile water. The second method was root immersion in conidial suspension. In this treatment, approximately $150 \mathrm{~mL}$ of the conidial suspension $\left(1 \times 10^{6}\right.$ conidia $\left.\cdot \mathrm{mL}^{-1}\right)$ was used, in which the previously cut roots were immersed for 5 minutes. Immediately after this, the seedlings were planted in pots containing sterile substrate. The control was immersed in sterile water for the same period. The third method was root wounding and inoculation of conidia without seedling transplant. In this procedure, plants were maintained in containers and inoculation involved root wounding and subsequent addition of $10 \mathrm{~mL}$ of conidial suspension $\left(1 \times 10^{6}\right.$ conidia $\left.\mathrm{mL}^{-1}\right)$ to this region. In the control treatment, 10 plants received only sterile water. The fourth method was inoculation with colonized ground corn. Ground corn 
fusarium-colonized was added to the substrate in the proportion of $40 \mathrm{~g} \cdot \mathrm{dm}^{-3}$. After mixing the inoculum to the substrate, seedlings two months of age were planted, previously cut in the apical region of roots, with previously flamed scissors. The control plants had the roots cut and were planted in pots containing $40 \mathrm{~g} . \mathrm{dm}^{-3}$ of ground corn without fungus. The design was completely randomized with 10 replicates.

Plants were kept in a greenhouse, and after 120 days plants were oven dried at $60^{\circ} \mathrm{C}$ and the total dry weight, dry weight of the roots, and dry weight of leaves and stem were determined. Number of leaves, plants height, and the severity of the disease were also evaluated. Severity was calculated by dividing the total sum of the lesions by roots dry weight, in order to homogenize the results, since plants with a small amount of roots have relatively less area to be colonized by the fungus.

\section{RESULTS AND DISCUSSION}

This study demonstrated that $F$. proliferatum can infect the leaves, stem, and roots of the peach palm. F proliferatum, FOSC, $F$. verticillioides, FSSC, and GFSC were verified to be pathogenic to the peach palm. The use of Fusariumcolonized ground corn for root inoculation was effective and reduced damage to plants.

At 7 days after inoculation (DAI), leaves inoculated with $F$. Proliferatum exhibited symptoms, characterized by blackening of leaf blade and veins (Figure 1A-C). In the re-isolation, the presence of $F$. proliferatum in all the leaf fragments was verified. Plants inoculated with saline alone showed no symptoms. At $15 \mathrm{DAI}$, the plants whose stems were inoculated with $F$. proliferatum showed characteristic external symptoms, including flag leaf yellowing, similar to that of fusariosis observed in the field. At 90 DAI, cut stems displayed tissues that were darkened internally (Figure 1G-I). Certain plants of the control group showed flag leaf yellowing. On cutting the stem, the tissues of the inoculated region were darkened internally (Figure $1 \mathrm{H}$ ), and no symptoms appeared at the injured region. Plants inoculated with $F$. proliferatum in the roots exhibited lesions reaching $15.2 \mathrm{~mm}$ in length (Figure $1 \mathrm{~F}$ ). There were no reflex symptoms in the upper parts of the inoculated plants. Isolates SP-3 and SP-5 resulted in the development of lesions up to $15.21 \mathrm{~mm}$ and $12.3 \mathrm{~mm}$ in length, respectively. In the re-isolation, $80 \%$ recovery of $F$. proliferatum was verified in the inoculated plants. Plants of the control group showed only dimming at the region of the inoculation wound.
Leaves, stems, and roots of peach palm were susceptible to $F$. proliferatum. Although, Fusarium is a soil pathogen (LESLIE \& SUMMERELL, 2006), its occurrence as a leaf pathogen has been reported for other palms, such as the date palm (HODEL, 2009). However, this is the first observation of susceptibility of peach palm leaves. Owing to its practicality and speed in obtaining results, the foliar inoculation method proved to be feasible for demonstrating the pathogenicity of Fusarium. However, it has the drawback of not reproducing the typical fusariosis symptoms.

Inoculation of the wounded stems reproduced the typical symptoms of fusariosis, which were characterized by flag leaf yellowing, followed by the yellowing of the other leaves (Table 1). However, wounds created during inoculation resulted in the death of up to $50 \%$ of the plants. In the longitudinal cuts on the stem, the inoculated regions were observed to occasionally be located near the apical meristem, resulting in irreversible damage to the plants (Figure 1H). Another aspect of this method that merits attention was that plants inoculated with Fusarium were externally asymptomatic. However, in the longitudinal cuts on these plant stems, active lesions reaching up to $95 \mathrm{~mm}$ of length were observed. This finding is important regarding the dissemination of the pathogen by asymptomatic seedlings in nurseries. In the re-isolation, the presence of Fusarium was verified in the stem fragments of plants of the control group. The endophytic origin of Fusarium in the cauline apices of peach palm has been previously reported by ALMEIDA et al. (2005). Similarly, other authors reported the presence of phytopathogenic fungi including Deightoniella torulosa and Colletotrichum spp. as endophytes in other hosts (PHOTITA et al., 2004; VIEIRA et al., 2014).

Plants inoculated with Fusarium exhibited typical symptoms of the disease, characterized by leaf yellowing that progressed until plant death. In this method (Experiment 2), disease incidence ranged from $10-80 \%$ upon inoculation with the most aggressive Fusarium isolates BG-14 and CA-1. In this study, in the control treatment, certain plants showed flag leaf yellowing, which caused the death of $50 \%$ of the plants. This phenomenon has already been observed in other studies, while inoculating peach palm stems, with injury (COSTA JÚNIOR, 2013). This situation is more common while using methods causing injury, and death results from damage to the meristematic region of the plant (Figure $1 \mathrm{G}-\mathrm{I}$ ) as discussed previously.

In the longitudinal sections of the stems of the seedlings inoculated with Fusarium, asymptomatic plants displayed characteristic internal symptoms that included tissue darkening (Figure 1-I). Moreover, 

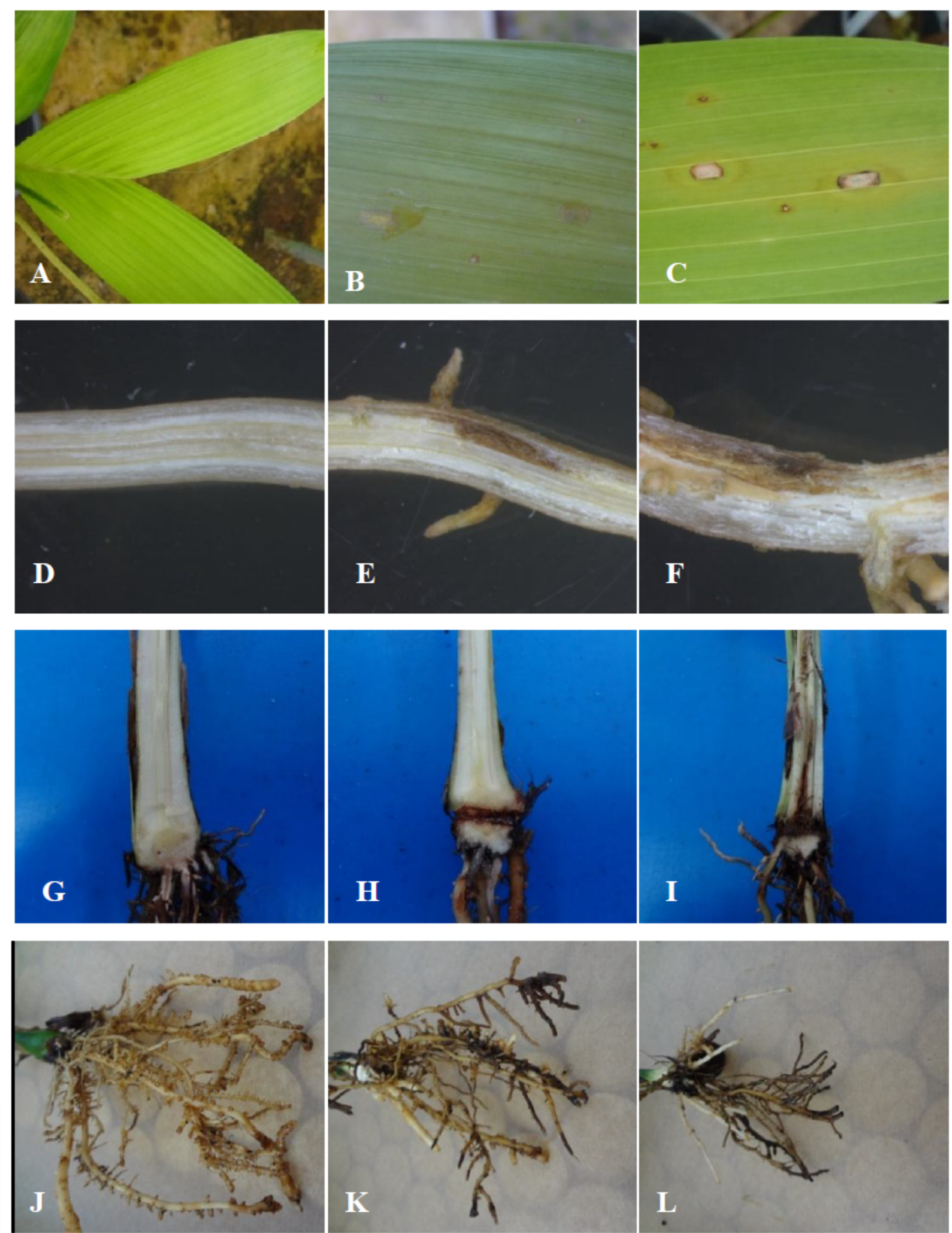

Figure 1 - A) Control treatment, leaf of peach palm inoculated with water. B) Symptoms on leaf inoculated with Fusarium proliferatum 7 days after inoculation (DAI). C) Symptoms on leaf 15 DAI. D) Longitudinal section root of noninoculated control treatment $(7.5 \times$ magnification). E) Control root inoculated with water $(7.5 \times$ magnification). F) Symptoms in roots inoculated with $F$. proliferatum $(7.5 \times$ magnification). G) Non-inoculated control in cross-sectional view. H) Control stem inoculated with water. I) Stem inoculated with Fusarium proliferatum. J) Roots of control for test maintained on substrate. K) Roots of the plant treated with ground corn without fungus (control). L) Roots of plant inoculated with F. proliferatum-colonized ground corn. 
evaluation of $F$. proliferatum in Phoenix dactylifera L. was conducted three months after inoculation, demonstrating that diseases caused byFusarium. in palm trees may slowly progress to demonstrate external symptoms (ABDALLA et al., 2000). The CA1A isolate of Fusarium that was initially one of the most aggressive did not maintain the same behavior in the second experiment. The same was observed for the SAF-7 isolate, while the BG-14 isolate maintained the same behavior in both experiments.
This non-reproducible behavior for some Fusarium isolates following inoculation for stem wounds has already been reported by other authors in peach palm (PIZZINATO et al., 2001; COSTA JÚNIOR, 2013).

In the comparison of the four inoculation methods (Figure 2), principal component analysis (PCA) revealed the influence of the treatments on the response variables, in which the severity vectors were positioned in the opposite direction to the vectors that indicated plant growth (height, dry weight of roots,
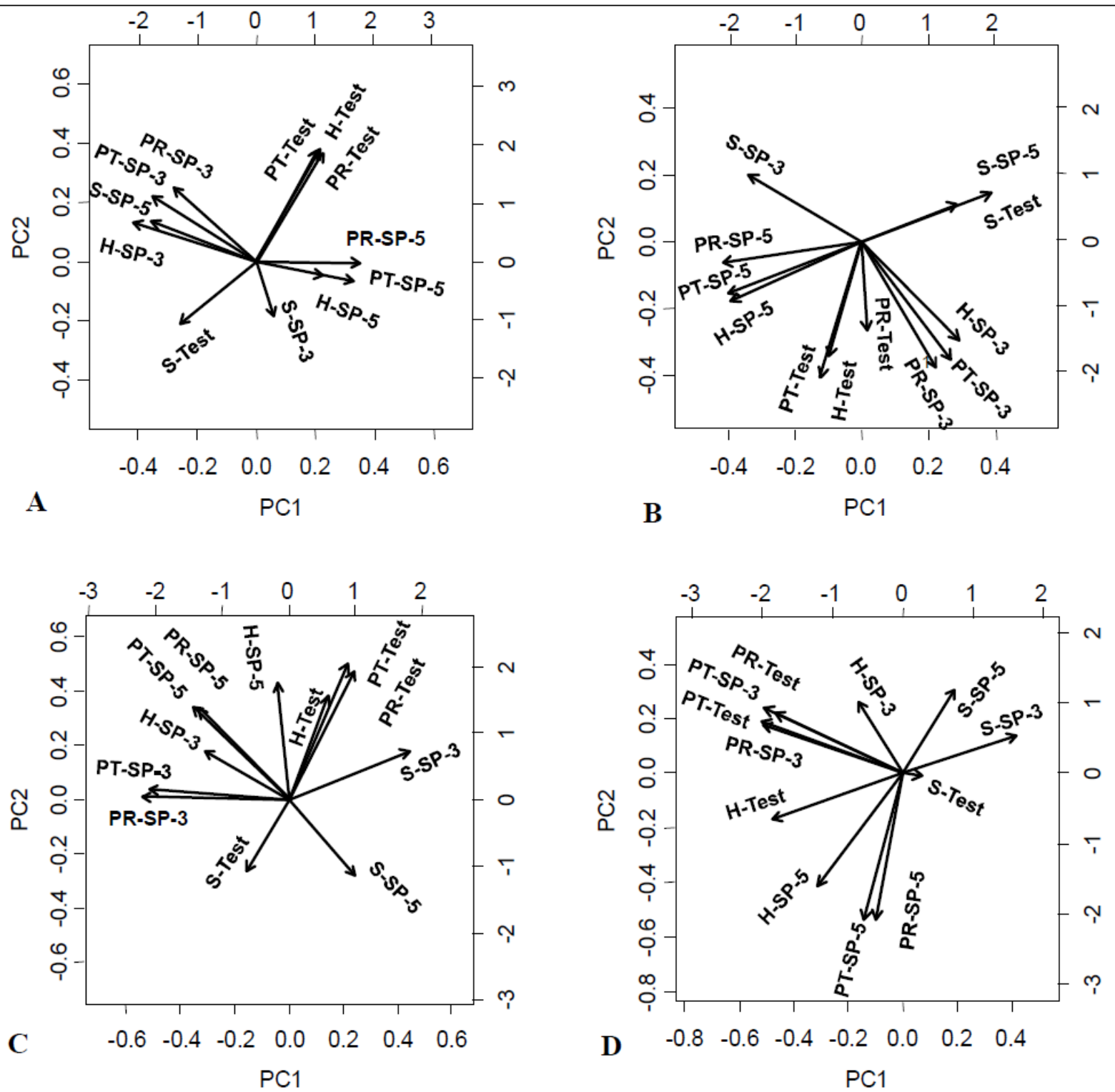

Figure 2 - Biplot of response height $(\mathrm{H})$, total weight (PT), root weight (PR), and severity (S) for analysis of main components using correlation matrix with SP-5 and SP-3 treatments and control (Test) for inoculation methods: A) injection, B) immersion, C) injury, and D) ground corn. 
and total dry weight). A location closer to the origin indicated a reduced contribution of the variable to the analysis, and the vectors of relative severity to control (S-Test) were always closer to the origin than the vectors of severity to the isolates (S-SP-3, S-SP5), except for the injection method (Figure 2). These results indicated that this method causes greater injury in the control compared to the symptoms of the inoculated plants.

In all treatments, the principal components 1 and 2 explained most of the total variance with proportions of $67 \%$ up to $79 \%$, which were similar to those obtained by KUHNEM JÚNIOR et al. (2013), and which explained $74.5 \%$ of the total variance between isolated from Fusarium spp. in corn. In this study, F. Proliferatum isolate SP-3 inoculated using the Fusarium-colonized ground corn method resulted in a lower plant height of $72 \mathrm{~mm}$, compared to the control height of $76 \mathrm{~mm}$. The other variables analyzed, total dry weight and dry weight of roots, also gave the same indication that inoculation with Fusarium-colonized ground corn reduced plant growth without affecting the control, since the self-value of severity in this treatment for the control was very low ( 0.05 in the main component 1). The root immersion treatment performed satisfactorily; however, the control group values were much higher $(0.27)$. The reduction of growth after inoculation with $F$. verticillioides via soil is known for the maize pathosystem, mainly at high levels of the inoculum (GLENN et al., 2008; COSTA et al., 2012).

The root wound method was the least aggressive because it did not transplant the seedlings during the inoculation. As a result, fewer roots injuries resulted in larger plants with higher dry weight. However, in this treatment less disease severity was found, which is not desirable for an inoculation method. Dry weight of roots reduced in the treatment with Fusarium-colonized ground corn, and the plants had on average $0.13 \mathrm{~g}$ of roots for the SP-3 isolate. This likely was a result of the colonization of the roots by $F$. proliferatum (Figure $1 \mathrm{D}-\mathrm{F}$ ), which requires a substrate for its establishment and survival until the time of colonization (COSTA et al., 2012).

\section{CONCLUSION}

F. proliferatum caused lesions on leaves, stem, and roots of the peach palm. F. proliferatum, $F$. oxysporum species complex, $F$. verticillioides, $F$. solani species complex, and Gibberella fujikuroi species complex were pathogenic to the peach palm. Root inoculation with Fusarium-colonized ground corn was the most suitable method for fusariosis.

\section{ACKNOWLEDGEMENTS}

We thank Coordenação de Aperfeiçoamento de Pessoal de Nível Superior (CAPES), and Conselho Nacional de Desenvolvimento Científico e Tecnológico (CNPq) for financial support.

\section{REFERENCES}

ABDALLA, M.Y. et al. Pathogenicity of toxigenic Fusarium proliferatum from Date Palm in Saudi Arabia. Plant disease, v. 84 , n.3, p.321-324, 2000. Available from: <https://apsjournals.apsnet. org/doi/pdf/10.1094/PDIS.2000.84.3.321>. Accessed: May 26, 2017. doi: 10.1094/PDIS.2000.84.3.321.

ALMEIDA, C.V. de et al. Endophytic fungi in shoot tip of the pejibaye cultivated in vivo and in vitro. Pesquisa Agropecuária Brasileira, v.40, n.5, p.467-470, 2005. Available from: <http://www. scielo.br/pdf/\%0D/pab/v40n5/24428.pdf>. Accessed: Jun. 07, 2017.

ALVES, S.A.R. et al. Patogenicidade de isolados de Fusarium spp. e Phytophthora palmivora associados com a Podridão do Estipe da Pupunheira no Paraná. Boletim Pesquisa Florestal, v.52, p.133140, 2006. Available from: <https://pfb.cnpf.embrapa.br/pfb/ index.php/pfb/article/view/218>. Accessed: Jun. 07, 2017.

COSTA JÚNIOR, J.C. Qualidade sanitária e fisiológica de sementes de pupunheira submetidas a tratamento químico e caracterização dos sintomas da podridão da base do estipe causada por Fusarium spp. 2013.Curitiba: UFPR. $127 \mathrm{p}$ (Dissertação Mestrado).

COSTA JÚNIOR, J.C.; et al. Sanitary and physiological quality, methods of detection and treatment of seeds of peach palm. Ciência Florestal, v. 26, n. 4, p.1119-1131, 2016. Available from: <http://www.redalyc.org/html/534/53449110008/>. Accessed: Jul. 05, 2017.

COSTA, R.V. et al. Metodologia para avaliação da reação de genótipos de milho à Fusarium verticillioides em casa de vegetação. Circular técnica Embrapa Milho e Sorgo, v.179, p.1-7, 2012. Available from: <https://www.researchgate.net/profile/Dagma Da_Silva2/publication/263785369_Metodologia_inoculacao_ fusarium casa de vegetacao/links/0 $\bar{c} 96053$ be 74 e148a85000000/ Metodologia-inoculacao-fusarium-casa-de-vegetacao.pdf $>$. Accessed: May 26, 2017.

DIHAZI, A. et al. Use of two bacteria for biological control of bayoud disease caused by Fusarium oxysporum in date palm (Phoenix dactylifera L) seedlings. Plant Physiology Biochemistry, v.55, p.7-15, 2012. Available from: <https://www.sciencedirect. com/science/article/pii/S0981942812000605>. Accessed: Jul. 05, 2017. doi: 10.1016/j.plaphy.2012.03.003.

GLENN, A.E. et al. Transformation-mediated complementation of a FUM gene cluster deletion in Fusarium verticillioides restores both fumonisin production and pathogenicity on maize seedlings. Molecular Plant-Microbe Interactions, v.21, n.1, p.87-97, 2008. Available from: <https://apsjournals.apsnet.org/doi/abs/10.1094/ MPMI-21-1-0087>. Accessed: May 22, 2017. doi: 10.1094/ MPMI-21-1-0087.

HODEL, D.R. 2009. Palm diseases in the landscape: Integrated pest management for home gardeners and landscape professionals. Davis: Pest notes, publication 74148: 1-6. 
KLINGELFUSS, L.H.et al. Inoculation methods for identification of resistance in soybean to Fusarium solani f. sp. glycines under greenhouse conditions. Fitopatologia brasileira, v.32, n.1, p.50-55, 2007. Available from: <http:// www.scielo.br/pdf/\%0D/fb/v32n1/07.pdf>. Accessed: Jun. 07, 2017.

KUHNEM JÚNIOR, P.R. et al. Pathogenic traits of Fusarium graminearum complex and Fusarium verticillioides isolates on seeds and seedlings of maize. Ciência Rural, v.43, n.4, p.583-588, 2013. Available from: <http://www.redalyc.org/ pdf/331/33125776009.pdf>. Accessed: Jun. 02, 2017.

LESLIE, J; SUMMERELL, B.A. The Fusarium laboratory Manual.USA: Iowa, 2006.
PHOTITA, W. et al. Are some endophytes of Musa acuminate latent pathogens? Fungal diversity, v. 16, p. 131-140, 2004. Available from: $<$ http://hub.hku.hk/handle/10722/223070>. Accessed: Mar. 15, 2017.

PIZZINATTO, M.A. et al. Patogenicidade de cinco espécies de Fusarium a plantas de pupunheira (Bactris gasipaes). Summa Phytopathologicav.27, p.263-266, 2001.

SANTOS, A.F. et al. Palmeiras para a Produção de Palmito: Juçara, Pupunheira e Palmeira Real. Colombo: Embrapa Florestas, 2008.

VIEIRA, W.A.S. et al. Endophytic species of Colletotrichum associated with mango in northeastern Brazil. Fungal diversity, v.67, p. 181-202, 2014. Available from: <https://link.springer.com/article/10.1007/s13225014-0293-6>. Accessed: Sept. 15, 2016. doi: 10.1007/s13225-014-0293-6. 